\title{
PERBEDAAN HASIL BELAJAR SISWA ANTARA MODEL KOOPERATIF TIPE TWO STAY TWO STRAY (TSTS) DENGAN GROUP INVESTIGATION (GI) DI KELAS V SDN 060934 MEDAN
}

\author{
Demmu Karo-Karo
}

Surel: demmukarokaro@gmail.com

\begin{abstract}
This study aims to determine differences in student learning outcomes between cooperative learning model type Two Stay Two Stray (TSTS) with Group Investigation (GI) model on science learning in grade V SDN 060934 Medan Academic Year 2017/2018. This research is a comparative research with experimental method. The population in the study were the students of class $V$ consisting of 2 classes amounting to 44 people. Sampling is done by saturated sampling that is all members of the population used as a sample of 2 classes. The experiment class 1 is 22 students and the experiment 2 class is 22 students. The instrument used to know the student's learning result is the test of learning result in multiple choice form.
\end{abstract}

Keywords: Learning Outcomes, Two Stay Two Stray Cooperative Model, Group Investigation.

\begin{abstract}
ABSTRAK
Penelitian ini bertujuan untuk mengetahui perbedaan hasil belajar siswa antara model pembelajaran kooperatif tipe Two Stay Two Stray (TSTS) dengan model Group Investigation (GI) pada pembelajaran IPA di kelas V SDN 060934 Medan Tahun Ajaran 2017/2018. Penelitian ini adalah penelitian komparatif dengan metode eksperimental. Populasi dalam penelitian adalah siswa kelas $\mathrm{V}$ yang terdiri dari 2 kelas berjumlah 44 orang. Pengambilan sampel dilakukan dengan cara sampling jenuh yaitu seluruh anggota populasi dijadikan sebagai sampel yang berjumlah 2 kelas. Kelas eksperimen 1 berjumlah 22 siswa dan kelas eksperimen 2 berjumlah 22 siswa.Instrumen yang digunakan untuk mengetahui hasil belajar siswa adalah tes hasil belajar dalam bentuk pilihan berganda.
\end{abstract}

Kata Kunci: Hasil Belajar, Model Kooperatif Two Stay Two Stray, Group Investigation.

\section{PENDAHULUAN}

Pembelajaran IPA adalah ilmu yang mempelajari peristiwaperistiwa yang terjadi di alam dengan observasi, eksperimen, penyimpulan, penyusunan teori. Pembelajaran IPA bertujuan agar siswa mempunyai pengetahuan, gagasan, mengembangkan rasa ingin tahu, keterampilan, mengembangkan kesadaran tentang peran dan pentingnya IPA dalam kehidupan sehari-hari untuk memenuhi kebutuhan manusia melalui pemecahan masalah-masalah yang dapat diidentifikasi.

Pembelajaran IPA yang baik dan benar di sekolah dasar memuat tiga komponen yaitu merangsang pertumbuhan intelektual dan perkembangan siswa, melibatkan siswa dalam kegiatan-kegiatan praktikum/percobaan tentang hakikat IPA, mendorong dan merangsang 


\begin{abstract}
terbentuknya sikap ilmiah, mengembangkan kemampuan penggunaan keterampilan IPA, menguasai pola dasar IPA, dan merangsang tumbuhnya sikap berpikir kritis dan rasional. Oleh karena itu pembelajaran IPA di SD/ MI menekankan pada pemberian pengalaman belajar secara langsung melalui penggunaan dan pengembangan keterampilan proses dan sikap ilmiah.
\end{abstract}

Berdasarkan pengamatan di lapangan, banyak ditemui pelaksanaan pembelajaran masih kurang variatif, proses pembelajaran memiliki kecenderungan pada model tertentu (konvensional), tidak memperhatikan tingkat pemahaman siswa terhadap informasi yang disampikan dan guru kurang melibatkan siswa secara langsung dalam proses pembelajaran. Siswa juga kurang aktif dalam proses belajar, siswa lebih banyak mendengar dan menulis, menyebabkan isi pelajaran sebagai hafalan sehingga siswa tidak memahami konsep yang sebenarnya. Tentunya hal ini juga menjadi salah satu penyebab rendahnya hasil belajar siswa yang menunjukkan masih terdapat beberapa siswa yang mendapat nilai dibawah KKM, padahal hasil belajar merupakan pencapaian tujuan pendidikan pada siswa yang mengikuti proses belajar mengajar.

Salah satu upaya mengatasi permasalahan diatas adalah guru harus mampu merancang model pembelajaran yang bermakna bagi siswa. Untuk itu, guru harus kreatif dalam mendesain model pembelajaran yang memungkinkan siswa dapat berpartisipasi, aktif, kreatif terhadap materi yang diajarkan. Salah satu model pembelajaran itu ialah model kooperatif yaitu model pembelajaran kelompok yang akhir-akhir ini menjadi perhatian dan dianjurkan para ahli pendidikan untuk digunakan. Peneliti memilih model pembelajaran kooperatif karena proses pembelajaran berpusat pada siswa sehingga diharapkan dapat meningkatkan hasil belajar siswa. Hal ini sesuai dengan pendapat para ahli berikut ini.

Slavin (dalam Wina Sanjaya, 2013: 242) alasan penggunaan model pembelajaran kooperatif antara lain: Pertama, beberapa hasil penelitian membuktikan bahwa penggunaan pembelajaran kooperatif dapat meningkatkan prestasi siswa sekaligus dapat meningkatkan kemampuan sosial, menumbuhkan sikap menerima kekurangan diri dan orang lain, serta dapat meningkatkan harga diri. Kedua, pembelajaran kooperatif dapat merealisasikan kebutuhan siswa dalam belajar berpikir, memecahkan masalah, dan mengintegrasikan pengetahuan dengan keterampilan.

Ada beberapa macam pembelajaran kooperatif diantaranya model pembelajaran kooperatif tipe Two Stay Two Stray (TSTS) dan model pembelajaran kooperatif tipe Group Investigation (GI). Dimana kedua model ini sama-sama 
membagi siswa menjadi beberapa kelompok dan siswa bekerja sama dengan kelompoknya, sehingga siswa dapat saling bekerjasama, bertukar informasi dan pengalaman belajar.

Untuk memudahkan pada pelaksanaan penelitian, peneliti membuat kerangka berpikir untuk dijadikan acuan dalam melaksanakan penelitiannya. Sugiyono (2014: 388) mengemukakan bahwa kerangka berpikir merupakan model konseptual tentang bagaimana teori berhubungan dengan berbagai faktor yang telah diidentifikasi sebagai masalah yang penting.

Berdasarkan uraian diatas dapat dipahami bahwa untuk mencapai hasil belajar yang maksimal dibutuhkan model pembelajaran yang bervariatif. Model yang digunakan dalam penelitian ini adalah model pembelajaran kooperatif tipe $T w o$ Stay Two Stray (TSTS) dan Group Investigation (GI). Kedua model ini merupakan pembelajaran yang melibatkan siswa dalam kelompok, tetapi dengan langka-langkah pembelajaran yang berbeda.

Pembelajaran dengan model kooperatif tipe Two Stay Two Stray (TSTS) memiliki langkah-langkah pembelajaran yang diawali dengan pembagian kelompok. Setelah kelompok terbentuk guru memberikan tugas berupa permasalahan-permasalahan yang harus mereka diskusikan jawabannya. Dalam penelitian ini materi yang diberikan adalah pesawat sederhana. Setelah diskusi antar kelompok, dua orang dari masing-masing kelompok pergi meninggalkan kelompoknya untuk bertamu kepada kelompok lain dan mencari informasi dari tuan rumah. Aggota kelompok lain yang tinggal, bertugas sebagai tuan rumah yang mempunyai kewajiban menyajikan hasil kerja kelompoknya kepada tamu tersebut. Setelah masingmasing kelompok menunaikan tugasnya, mereka kembali ke kelompoknya dan membahas hasil kerja yang telah mereka tuntaskan. Guru kemudian mengarahkan masing-masing kelompok untuk membahas permasalahanpermasalahan yang telah dibahas.

Tahap-tahap pembelajaran Group Investigation (GI) diawali dengan guru membagi kelompok, selanjutnya guru beserta siswa memilih topik, dalam penelitian ini topik atau materi yang diberikan adalah pesawat sederhana. Untuk selanjutnya setiap kelompok bekerja berdasarkan model investigasi, aktivitas tersebut merupakan kegiatan sistemik keilmuan mulai dari setiap kelompok mengumpulkan data, analisis data, sintesis, hingga menarik kesimpulan. Langkah berikutnya adalah presentasi hasil diskusi atau kerja tiap masingmasing kelompok. Untuk selanjutnya guru beserta siswa di akhir pembelajaran melakukan evaluasi.

Penelitian ini dilakukan dengan tahap mengadakan pretes yaitu mengadakan tes untuk mengetahui kemampuan awal siswa materi 
pelajaran tubuh manusia yang akan disampaikan baik di kelas eksperimen 1 maupun dikelas eksperimen 2 dengan soal tes yang sama. Kemudian perlakuan mengajar yaitu mengajar dengan menggunakan model pembelajaran kooperatif tipe Two Stay Two Stray pada kelas eksperimen 1 dan memberikan perlakuan mengajar dengan menggunakan model pembelajaran kooperatif tipe Group Investigation (GI) pada kelas eksperimen 2. Setelah dilakukan perlakuan mengajar maka langkah selanjutnya adalah mengadakan post tes yaitu mengadakan tes untuk mengetahui hasil belajar siswa mengenai materi pesawat sederhana yang telah disampaikan dengan soal yang sama antara kelas eksperimen 1 dengan kelas eksperimen 2, untuk selanjutnya dibandingkan perbedaan dari hasil belajar menggunakan kedua model tersebut.

\section{METODE PENELITIAN}

Jenis penelitian ini adalah penelitian komparatif dengan metode eksperimental dan data kuantitatif yang bertujuan untuk melihat atau mengetahui adanya perbedaan hasil belajar siswa dengan menggunakan model pembelajaran kooperatif tipe Two Stay Two Stray (TSTS) dan dengan model pembelajaran kooperatif kooperatif tipe Group Investigation (GI).

Penelitian ini dilakukan di SDN 060934 Medan semester genap T.A 2017/2018. Penelitian ini dilaksanakan pada bulan Januari sampai dengan Maret tahun 2018.

Populasi pada penelitian ini adalah seluruh siswa kelas V SDN 060934 Medan Tahun Ajaran 2017/2018 yang berjumlah 44 siswa dengan jumlah, siswa kelas $\mathrm{V}$ A berjumlah 22 siswa dan kelas V B berjumlah 22 siswa.

Pengambilan sampel dalam penelitian ini dilakukan dengan cara sampling jenuh, yaitu teknik penentuan sampel bila semua anggota populasi digunakan sebagai sampel. Satu kelas dijadikan sebagai kelas eksperimen1 yaitu kelas yang diajar dengan pembelajaran kooperatif tipe Two Stay Two Stray (TSTS) dan satu kelas lagi dijadikan sebagai kelas eksperimen 2 yaitu kelas yang diajarkan dengan pembelajaran kooperatif tipe Group Investigation (GI).

Variabel dalam penelitian ini adalah sebagai berikut:

a. Variabel Terikat

Variabel terikat (Y) dalam penelitian ini adalah hasil belajar

b. Variabel Bebas

Variabel bebas (X) dalam penelitian ini adalah $\left(X_{1}\right)$ model pembelajaran kooperatif tipe $T w o$ Stay Two Stray (TSTS) dan $\left(X_{2}\right)$ model pembelajaran kooperatif tipe Group Investigation (GI).

Penelitain ini merupakan penelitian Quasi Eksperimen yaitupenelitian melibatkan dua kelas yang diberi perlakuan yang berbeda.Di dalam penelitian ini sebelum dimulai perlakuan kedua kelompok diberi tes awal atau pre- 
Demmu Karo-Karo: Perbedaan Hasil Belajar...

testuntukuntuk mengukur kondisi awal ( $\left.T_{1}\right)$.Selanjutnya pada kelompok eksperimen diberi perlakuan $\left(X_{1}\right)$ dan kelompok kontrol diberi perlakuan $\left(X_{2}\right)$. Sesudah selesai perlakuan kedua kelompok diberi tes lagi sebagai tes akhir atau post-test.

\section{Tabel 1. Two Group Pre-test, Post- test Design}

\begin{tabular}{l|c|c|l}
\hline Kelas & $\begin{array}{l}\text { Pre } \\
\text { test }\end{array}$ & $\begin{array}{l}\text { Perlakua } \\
\mathrm{n}\end{array}$ & $\begin{array}{l}\text { Pos } \\
\text { test }\end{array}$ \\
\hline $\begin{array}{l}\text { Eksperime } \\
\text { n 1 }\end{array}$ & $\left(T_{1}\right)$ & $X_{1}$ & $\left(T_{2}\right)_{E}$ \\
\hline $\begin{array}{l}\text { Eksperime } \\
\text { n 2 }\end{array}$ & $\left(T_{1}\right)$ & $X_{2}$ & $\left(T_{2}\right)_{K}$ \\
\hline
\end{tabular}

(Sumber Arikunto, 2014: 125)

Keterangan:

$\begin{aligned} X_{1}= & \text { Pembelajaran dengan } \\ & \text { model pembelajaran } \\ & \text { kooperatif tipe TwoStay } \\ & \text { Two Stray (TSTS). } \\ X_{2}= & \text { Pembelajaran dengan } \\ & \text { model pembelajaran } \\ & \text { kooperatif tipe Group } \\ & \text { Investigation }(\mathrm{GI}) . \\ \left(T_{1}\right)_{E}= & \text { Pretest diberikan pada } \\ & \text { kelas eksperimen sebelum } \\ & \text { perlakuan. } \\ \left(T_{1}\right)_{K}= & \text { Pretest diberikan pada } \\ & \text { kelas kontrol sebelum } \\ & \text { perlakuan. } \\ \left(T_{2}\right)_{E}= & \text { Postest diberikan setelah } \\ & \text { perlakuan pada kelas } \\ & \text { kontrol. }\end{aligned}$

\section{HASIL PENELITIAN DAN PEMBAHASAN PENELITIAN}

Instrumen penelitian yang digunakan dalam penelitian ini adalah tes soal yang merupakan instrumen atau alat ukur yang digunakan untuk mengumpulkan data hasil belajar dengan cara mengukur atau mengujikannya. Sebagai sebuah alat ukur maka tes hasil belajar harus memenuhi persyaratan yang dituntut untuk dimiliki oleh sebuah alat ukur yang baik sebagaimana alat ukur yang digunakan untuk mengumpulkan data. Alat ukur pengumpulan data harus memenuhi dua syarat yaitu validitas dan reliabilitas.Uji coba instrumen dilakukan di SD Negeri 060934 Medan dengan jumlah 30 orang siswa dengan jumlah soal yang di uji coba adalah sebanyak 40 soal.

Pada awal penelitian kedua kelompok sampel diberikan pretest untuk mengetahui kemampuan awal siswa sebelum diberikan perlakuan. Dari nilai pretest, diketahui bahwa kelas eksperimen 1 sebagai kelas yang akan diberikan perlakuan dengan model pembelajaran kooperatif tipe Two Stay Two Stray (TSTS) memiliki nilai rata-rata 46,09 sedangkan pada kelas eksperimen 2 yang akan diberikan perlakuan model pembelajaran kooperatif tipe Group Invetigation (GI) memiliki nilai rata-rata 45,54.

Kemudian hasil penelitian uji $\mathrm{t}$ untuk melihat uji kesamaan ratarata pretest kedua kelas diperoleh $t_{\text {hitung }}<t_{\text {tabel }}$ yaitu $0,354<2,018$. Hal ini membuktikan bahwa 
kemampuan awal siswa pada kelas eksperimen 1 sama dengan kemampuan awal siswa pada kelas eksperimen 2 .

Setelah diberikan pretest langkah selanjutnya dalam penelitian ini adalah kedua kelas diajarkan dengan model pembelajaran yang berbeda, pada kelas eksperimen 1 dengan model pembelajaran kooperatif tipe Two Stay Two Stray (TSTS) dan kelas eksperimen 2 dengan model pembelajaran kooperatif tipe Group Invetigation (GI). Materi yang diberikan sama yaitu materi pesawat sederhana.

Pada kelas ekperimen1, peneliti memberikan LKS pada kelompok yang sudah dibentuk kemudian masing-masing kelompok dibagikan sub materi untuk dibahas. Selama kegiatan pembelajaran menggunakan model Two Stay Two Stray (TSTS), kondisi yang berlangsung ialah siswa sangat aktif melakukan pembelajaran, hal ini dibuktikan dengan antusias siswa dalam menjelaskan informasi dan media yang dibawa oleh guru kepada kelompok yang berkunjung. Hasil LKS juga menunjukkan bahwa informasi yang disusun sangat baik.

Selanjutnya di kelas eksperimen 2 peneliti juga memberikan LKS dan media yang sama. Selama kegiatan pembelajaran menggunakan model Group Invetigation (GI) siswa kurang aktif dalam pembelajaran, hal ini dibuktikan kurang aktifnya siswa dalam bertanya pada kelompok yang melakukan presentasi di depan kelas.
Setelah seluruh materi selesai diajarkan, kedua kelas diberikan postest untuk mengetahui hasil belajar siswa setelah diberikan perlakuan yang berbeda. Adapun nilai rata-rata postest kelas eksperimen 1 adalah 71,81 sedangkan kelas eksperimen 2 memiliki nilai rata-rata 68,81 . Untuk mengetahui perbandingan hasil belajar kedua kelompok sampel kemudian dilakukan pengujian hipotesis dengan uji t, dari hasil perhitungan diperoleh nilai $t_{\text {hitung }}>t_{\text {tabel }}$ yaitu $2,771>2,018$ yang berarti hasil belajar siswa dengan menggunakan model pembelajaran kooperatif tipe Two Stay Two Stray (TSTS) lebih besar dari hasil belajar siswa dengan menggunakan model pembelajaran kooperatif tipe Group Investigation (GI) dan dapat disimpulkan bahwa terdapat perbedaan hasil belajar antara kedua model tersebut dimana hasil belajar model pembelajaran kooperatif tipe Two Stay Two Stray (TSTS) lebih baik dari pada hasil belajar siswa yang diajar dengan pembelajaran kooperatif tipe Group Investigation (GI) pada materi Pesawat Sederhana.

Hal ini didukung dengan penelitian yang relavan oleh peneliti lainnya yaitu penelitian yang dilakukan olehReziono Pratama dan Sajaratud Dur pada tahun 2016 dalam jurnalnya yang berjudul: Perbedaan Hasil Belajar Matematika Siswa yang Diajar dengan Model Pembelajaran Kooperatif Tipe Group Investigation (GI) dan Tipe Two Stay 
Demmu Karo-Karo: Perbedaan Hasil Belajar...

Two Stray (TSTS) pada Materi Persegi Panjang dan Persegi di Kelas VII SMP IT Al-Hijrah Deli Serdang Tahun Pelajaran 2015/ 2016 dengan temuan hipotesis pertama memberikan kesimpulan bahwa: hasil belajar siswa yang diajar dengan pembelajaran kooperatif tipe Two Stay-Two Stray (TSTS) lebih baik dari pada hasil belajar siswa yang diajar dengan pembelajaran kooperatif tipe Group Investigation (GI) pada materi Persegi Panjang dan Persegi di Kelas VII SMP IT ALHijrah Deli Serdang. Kemudian penelitian yang dilakukan oleh Fitria Sri Ratu pada tahun 2015 dalam jurnalnya yang berjudul : Perbedaan Hasil Belajar Matematika Siswa yang Diajar dengan Model Pembelajaran Kooperatif Tipe Group Investigation dan Tipe Two Stay Two Stray pada Materi Operasi Aljabar Kelas VII SMP Negeri 1 Binjai T.A 2014/2015. Dari analisis data skor post test dengan menggunakan uji-t pada taraf $\alpha=$ 0,05 diperoleh thitung $>$ ttabel yaitu 2,915 > 1,6676 maka Ho ditolak dan Ha diterima.

\section{Pembahasan}

Dari kedua penelitian diatas menunjukkan bahwa terdapat perbedaan hasil belajar yang diajarkan dengan model pembelajaran kooperatif tipeTwo Stay Two Stray (TSTS) dan yang diajarkan dengan model pembelajaran kooperatif tipe GroupInvestigation (GI).
Maka dari penelitian ini dapat disimpulkan bahwa ada perbedaan hasil belajar siswa yang diajarkan dengan menggunakan model pembelajaran kooperatif tipe Two Stay Two Stray (TSTS) dan model pembelajaran kooperatif kooperatif tipe Group Investigation (GI) pada materi pesawat sederhana di kelas $\mathrm{V}$ SDN 060934 Medan Tahun Ajaran 2017/2018.

\section{SIMPULAN}

Berdasarkan hasil penelitian yang diperoleh dari hasil analisa data dan pengujian hipotesis maka dapat disimpulkan sebagai berikut:

a. Rata-rata hasil belajar siswa pada kelas eksperimen 1 yang diberi perlakuan dengan model pembelajaran kooperatif tipe Two Stay Two Stray (TSTS) adalah 71,81 yang tergolong baik.

b. Rata-rata hasil belajar siswa pada kelas eksperimen 2 yang diberi perlakuan dengan model pembelajaran kooperatif tipe Group Investigation (GI) adalah 68,81 yang tergolong cukup baik.

c. Berdasarkan hasil perhitungan uji $t$ diperoleh bahwa $t_{\text {huitung }}>t_{\text {tabel }}$ yaitu 2,666> 2,018 maka Ho ditolak dan Ha diterima. Yang berarti ada perbedaan hasil belajar siswa antara model pembelajaran kooperatif tipe Two Stay Two Stray (TSTS) dengan Group Investigation (GI) pada Pembelajaran IPA di Kelas V SDN 060934 Medan Tahun Ajaran 2017/2018". 
DAFTAR RUJUKAN

Arikunto, Suharsimi. 2014. Prosedur

Penelitian. Jakarta: Rineka Cipta.

Hamdani. 2011. Strategi Belajar Mengajar. Bandung: Pustaka Setia.

Hamdayana, Jumanta. 2016. Metodologi Pengajaran. Jakarta: Sinar Grafika Offset.

Huda, Miftahul. 2014. Model-Model Pengajaran dan Pembelajaran. Yogyakarta: Pustaka Pelajar.

Ibnu, Trianto. 2014. Mendesain Model Pembelajaran Inovatif, Progresif, dan Kontekstual. Jakarta:

Prenadamedia Group.

Istarani. 2015. 58 Model Pembelajaran Inovatif. Medan: Media Persada.

Ngalimun. 2013. Strategi dan Model Pembelajaran. Yogyakarta: Aswaja Pressindo.

Purwanto. 2017. Evaluasi Hasil Belajar. Yogyakarta: Pustaka Pelajar.

Sani, Abdullah. 2014. Inovasi Pembelajaran. Jakarta: Bumi Aksara.
Sanjaya, Wina. 2013. Strategi Pembelajaran Berorientasi Standar Proses Pendidikan. Jakarta: Kencana. Shoimin, Aris. 2016. 68 Model Pembelajaran Inovatif dalam Kurikulum 2013. Yogyakarta: Ar-ruzz Media.

Slavin. 2016. Cooperative Learning Teori Riset dan Praktik. Bandung: Nusa Media.

Sumantri, Syarif. 2015. Strategi Pembelajaran Teori dan Praktik di Tingkat Pendidikan Dasar. Jakarta: Raja grafindo Persada.

Sudjana. 2005. Metoda Statistika. Bandung: Tarsito.

Sugiyono. 2015. Metode Penelitian Pendidikan (Pendekatan Kuantitatif, Kualitatif). Bandung: Alfabeta.

Suprijono, Agus. 2010. Cooperative Learning. Yogyakarta: Pustaka Pekajar.

Susanto, Ahmad. 2016. Teori Belajar dan Pembelajaran di Sekolah Dasar. Jakarta: Prenada media Group. 